\title{
CORRESPONDENCE
}

\section{OCULAR TORTICOLLIS}

\section{To the Editors of THE BRITISH JOURNAL OF OPHThalmology.}

SIR,-Mr. Temple-Smith, in a letter appearing in your September issue, criticises some of the statements in the brief abstract published in the Brit. Jl. of Ophthal. of a paper on ocular torticollis read by me at the last meeting of The Ophthalmological Society.

It is impossible adequately to discuss in a short letter many of the points he has raised, and most of them were dealt with at some length in my paper, which will be published in full in the forthcoming volume of the Transactions. To this I must refer $\mathrm{Mr}$. Temple-Smith for further elucidation of my views on the subject.

Yours truly,

W. H. MCMullen.

LONDON,

September 27, 1934.

\section{OBITUARY}

\section{W. C. POSEY}

WE much regret to learn that Dr. Posey died suddenly at Naples on September 5, just as he had embarked on his homeward journey to the States.

William Campbell Posey was born in Philadelphia in 1868, the son of Dr. David Posey. Educated at the Episcopal Academy, he proceeded to the University of Pennsylvania and qualified in 1889. After the customary period as House Surgeon, he spent a couple of years in post-graduate study in Berlin, Göttingen, Paris and London, where he worked at Moorfields. Posey was connected with numerous hospitals, the chief of which was the Wills Hospital, where he was Assistant Surgeon from 1893 to 1902, and afterwards Surgeon. With Dr. S. H. Brown he was the author of the History of Wills Hospital and traced the growth 